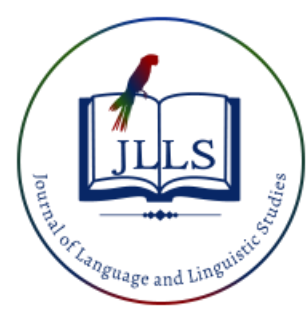

Available online at www.jlls.org

JOURNAL OF LANGUAGE AND LINGUISTIC STUDIES

ISSN: 1305-578X

Journal of Language and Linguistic Studies, 16(3), 1237-1250; 2020

\title{
Making requests to professors in emails: An examination of request modifications performed by Indonesian students in Japan
}

\author{
Rezky Pratiwi Balman a iD, Sangmok Lee ${ }^{\text {b }}$ iD \\ ${ }^{a}$ Kyushu University, Fukuoka, Japan \\ ${ }^{b}$ Kyushu University, Fukuoka, Japan
}

\section{APA Citation:}

Balman, R. P., \& Lee, S. (2020). Making requests to professors in emails: An examination of request modifications performed by Indonesian students in Japan. Journal of Language and Linguistic Studies, 16(3), 1237-1250.

Submission Date:10/03/2020

Acceptance Date:21/07/2020

\begin{abstract}
This paper examines email requests sent by Indonesian students to Japanese university professors using English as their lingua franca. It particularly analyzes how students modify their email requests using internal and external modifications as a way to soften the force of the imposed requests. Data were gathered from a total of 56 authentic emails and analyzed using a framework contrived by Economidou-Kogetsidis (2011), a modified Cross-Cultural of Speech Act Realization Patterns (CCSARP) coding scheme initially developed by Blum-Kulka, House \& Kasper (1989). The result showed that while Indonesian students barely use the internal modifications to soften the imposition of their written requests, they tend to rely more on the use of external modifications using supporting moves. This strategy can indirectly modify the illocutionary force of the request as the students ensure that they provide their professors with enough background information and justify the reason behind their request through grounder moves. This present study also shows a shift in students' communication style where brevity is highly preferable.
\end{abstract}

(C) 2020 JLLS and the Authors - Published by JLLS.

Keywords: e-mail; intercultural communication; request modifications; pragmatic; Indonesians

\section{Introduction}

Email has become a widely accepted medium of communication, giving students the convenience to reach their university lecturer quickly. Chen (2006) notes that email is a hybrid discourse derived from both written and spoken language features. It is believed that there are as yet no predetermined standard email writing rules which cause uncertainties regarding the style and politeness strategies (BiesenbachLucas, 2006). As a result, students who use English as their second or foreign language will have difficulties in writing emails to their university professors as they have to deal not only with grammar accuracy in the target language but also a need to give special attention to the politeness conventions applied in the asymmetrical student-professor relationship.

Meanwhile, a great deal of research on the intercultural speech act of request has been centered on speakers' request strategies (e.g., Al-Gahtani \& Roever, 2013; Fukushima, 1996; Hassal, 1999). The 
requesting strategy is one factor that determines the pragmatic success, while another one is the inclusion of the optional request modifications (Faerch \& Kasper, 1989). The present study concentrates on the request modification strategies performed by non-native speakers (henceforth NNS), i.e., Indonesian students, when making electronic requests. It focusses on the use of internal and external modifications as a way to soften or to intensify the force of the requests sent to Japanese university professors using English as their lingua franca.

\subsection{Literature review}

\subsubsection{Requests}

Requests by nature are face-threatening acts for both speaker $(\mathrm{S})$ and the hearer $(\mathrm{H})$ (Brown and Levinson, 1987). When $\mathrm{S}$ requests, $\mathrm{S}$ mentions that $\mathrm{S}$ needs something from $\mathrm{H}$, and equally, $\mathrm{S}$ gives $\mathrm{H}$ a degree of imposition and compliance (Searle,1969). Because of this, S must make use of both linguistic and pragmatic resources s/he has to show that $\mathrm{S}$ considers H's face and for politeness. One way to reduce the face-threat and minimize the imposition of the force of the request is through formulating request modification strategies using internal and external modifications. Understanding such mitigating devices is crucial to determine the success of a request. Failing to do so will not only make the speaker's request get refused, but also the speaker (S) can lose his/her face, and his/her politeness attitude can come to question.

\subsubsection{Internal and external modifications}

Internal modifications have been defined as "elements within the head act (the core part of a request sequence which realizes a request), the presence of which is not essential for the utterance to be potentially understood as a request" (Blum-Kulka et al., 1989, p. 60). Their roles are seen either as downgraders meant to soften the requests or as upgraders, meant to intensify the coerciveness of a request. The internal modifiers can be in the form of syntactic downgraders such as interrogative, conditional, negation, past tense, or in the form of lexical/phrasal downgraders. Lexical/phrasal downgraders "serve as optional additions to soften the imposition force of the request by modifying the head act internally through specific lexical and phrasal choices" (Blum-Kulka et al., 1989, p. 283). For instance, the downtoner 'possibly' in 'Can you possibly check my last draft I sent last week?' helps to soften the requests. The present study only focuses on internal modifications relating to lexical/phrasal downgraders and upgraders.

Similarly, external modifications also serve to either soften or emphasize the request force. External modifications do not affect the utterance used for realizing the request act (as what the internal modification does); instead, external modification affects the context which is embedded, and this indirectly modifies the illocutionary force (Blum-Kulka \& Olshtain, 1984). It occurs either before and/or after the request head act. For instance, the use of disarmer and grounder in 'I know you are busy, but can you check the last draft I sent last week? The deadline is approaching, and I need your feedback'. The disarmer as in 'I know you are busy, but' helps "the speaker to remove potential objection the hearer might raise upon being confronted with the request" (Blum-Kulka et al., 1989, p. 287), and the grounder provides explanations on why the request is performed.

\subsubsection{Previous research on email request modifications}

There has been a number of research exploring how L2 learners modify their requests and indicate that there is a tendency of NNSs from different language backgrounds are generally underused internal modification in their email requests (see Biesenbach-Lucas, 2004, 2007; Economidou-Kogetsidis 2011; Hartford \& Bardovi-Harlig, 1996; Hendriks, 2010; Pan, 2012). Research on requests indicates that students have a preference to modify their requests through external modifiers rather than internal modifiers (see Economidou-Kogetsidis, 2009; Faerch \& Kasper, 1989; Hassall, 2001). 
Among the restricted range of internal modifiers used, the NNSs show a slightly divergent in terms of their preferred modifiers. For instance, Hendriks (2010) found Dutch EFL learners underused lexical downtoners (e.g., possibly) and understaters (e.g., just) but prefer more to use subjectivisers (e.g., I was wondering). Biesenbach-Lucas $(2004,2007)$ studied NNSs from Asian backgrounds (Korea, Japan, Taiwan, and Thailand) and found the marker 'please' as the most preferred lexical modifier. The tendency to use this modifier was also favored by Arab speakers (Deveci \& Hmida, 2017).

Economidou-Kogetsidis (2011) reported the same tendency of NNS (Greek Cypriot) university students when mitigating their email requests to faculty members in an English medium university in Cyprus. Most of the emails used no marking (zero markings), marker 'please', or with consultative devices while other lexical modifiers were barely used. In regards to the external modifiers, most of their email messages were modified using supportive moves with grounders and pre-closing/thanks as the most widely used modifiers. A similar pattern was also found in NNSs (Iranian) students' email requests and whom the email recipients, i.e., Iranian faculty members perceived as causing a pragmatic failure, Zarei \& Mohammadi (2012).

Despite the growing number of studies investigating the request modifications, there is only a little work conducted which has provided a detailed account of linguistic production on request modification written by NNS students to NNS university professors (an exception to Zarei \& Mohammadi (2012)). Despite the growing number of NNS students study in non-native English speaking (NNES) countries, e.g., Japan, there have been no studies that have examined the case of NNSs, i.e., Indonesian students' pragmatic performance when communicating with NNSs, i.e., Japanese speakers in a study abroad context. The present study aims to fill this gap and adds to the body of knowledge of NNSs learners' verbal behavior in student-professors' email communications.

\subsection{Research questions}

This present study investigated the pragmalinguistics strategies used by NNS students to modify their email requests to their NNS professors. It tries to answer the following questions:

1. How do Indonesian students use internal modifications, i.e., lexical/phrasal downgraders, when writing email requests to their Japanese professors?

2. To what extent do Indonesian students use external modifications as their mitigating devices to soften the force of their requests in email?

\section{Method}

\subsection{Participants}

The participants in this study were 10 Indonesian graduate students from several study programs, including agriculture, engineering, and social sciences, in a Japanese public university. These students were first and second-year students whose age ranges are from 25-33 years. In terms of English proficiency, they vary from intermediate to advance levels. All of the participants started learning English from elementary schools in Indonesia and had never lived or studied in an English-speaking country before.

\subsection{Data collection procedures}

Once the participants agreed to participate, they were asked to forward up to 10 emails they have. As a result, 56 email requests served as the primary data. The email messages were authentic email 
messages containing requests from students to professors in university interaction. The types of requests were: Requests for information (e.g., "Could sensei (Japanese: teacher/professor) give a good suggestion on paper or book...?"), Requests for permission (e.g., "If it is possible, I would like to participate in this event"), Requests for meeting (e.g., "When do Sensei have free time for the next meeting?"), Requests for feedback (e.g., "I hope Sensei have some time to give some feedback"), Requests for action (e.g., "Is it possible for you to write me a recommendation?"). All emails collected were only student-initiated requests, which mean that emails that were part of follow-up requests in a chain of messages were omitted.

\subsection{Data analysis}

The requests were analyzed concerning the internal modifications (lexical/phrasal downgraders and upgraders) and external modifications (supporting moves and aggravating moves) following the modified Blum-Kulka et al.'s (1989) CCSARP coding framework derived from the email request study of Economidou-Kogetsidis (2011).

The first step was to identify the request head acts. Following this step, we then coded and classified each of these request head acts that carried any internal modifications. This allowed us to calculate the frequency of occurrence and the type of internal modifications employed. The coding schemes for internal modifications are displayed in Tables 1 and 2.

Table 1. Internal modification coding framework (Lexical/phrasal downgraders)

(Economidou-Kogetsidis, 2011, p. 3211)

\begin{tabular}{|c|c|c|}
\hline Name & Explanation & Devices \\
\hline Marker 'please' & $\begin{array}{l}\text { "An optional element added to a request to bid for } \\
\text { cooperative behaviour" (Blum-Kulka et al., 1989, p. } \\
\text { 283). }\end{array}$ & 'please' \\
\hline $\begin{array}{l}\text { Consultative } \\
\text { devices }\end{array}$ & $\begin{array}{l}\text { "expressions by means of which the speaker seeks to } \\
\text { involve the hearer directly bidding for cooperation" } \\
\text { (Blum-Kulka et al., 1989, p. 283). }\end{array}$ & $\begin{array}{l}\text { 'would you mind', 'do you } \\
\text { think', 'would it be all right } \\
\text { if', 'is it/would it be possible', } \\
\text { 'do you think I could...', 'is it } \\
\text { all right?' }\end{array}$ \\
\hline Downtoners & $\begin{array}{l}\text { "modifiers which are used by a speaker in order to } \\
\text { modulate the impact his or her request is likely to have } \\
\text { on the hearer" (Blum-Kulka et al., 1989, p. 284). }\end{array}$ & $\begin{array}{l}\text { 'possibly', 'perhaps', 'just', } \\
\text { 'rather', 'maybe', 'by any } \\
\text { chance', 'at all' }\end{array}$ \\
\hline $\begin{array}{l}\text { Understarters/ } \\
\text { hedges }\end{array}$ & $\begin{array}{l}\text { "adverbial modifiers by means of which the speaker } \\
\text { underrepresents the state of affairs denoted in the } \\
\text { proposition" (Blum-Kulka et al., 1989, p. 283). }\end{array}$ & $\begin{array}{l}\text { 'a bit', 'a little', 'sort of', } \\
\text { 'a kind of' }\end{array}$ \\
\hline Subjectivisers & $\begin{array}{l}\text { "elements in which the speaker explicitly expresses his } \\
\text { or her subjective opinion vis-a -vis the state of affairs } \\
\text { referred to in the proposition, thus lowering the } \\
\text { assertive force of the request" (Blum-Kulka et al., } \\
\text { 1989, p. 284). }\end{array}$ & $\begin{array}{l}\text { 'I'm afraid', 'I wonder', } \\
\text { 'I think/suppose' }\end{array}$ \\
\hline Cajolers & $\begin{array}{l}\text { "conventionalized, addressee-oriented modifiers } \\
\text { whose function is to make things clearer for the } \\
\text { addressee and invite him/her to metaphorically } \\
\text { participate in the speech act" (Sifianou, 1992, p. 180). }\end{array}$ & 'You know', 'You see...' \\
\hline Appealers & $\begin{array}{l}\text { Addressee-oriented elements occurring in a } \\
\text { syntactically final position. They may signal turn- } \\
\text { availability and "are used by the speaker whenever he } \\
\text { or } \\
\text { she wishes to appeal to his or her hearer's benevolent } \\
\text { understanding" (Blum-Kulka et al., 1989, p. 285). }\end{array}$ & $\begin{array}{l}\text { 'Clean the table dear, } \\
\text { will you? } \\
\text {....ok/right?') }\end{array}$ \\
\hline
\end{tabular}


Table 2. Internal modification coding framework - Upgraders-intensifiers (Economidou-Kogetsidis, 2011, p. 3211)

\begin{tabular}{lll}
\hline \multicolumn{1}{c}{ Name } & \multicolumn{1}{c}{ Explanation } & \multicolumn{1}{c}{ Devices } \\
\hline Intensifier & $\begin{array}{l}\text { "Adverbial modifier that stresses specific elements of } \\
\text { the request" (Schauer, 2009, p. 91) }\end{array}$ & $\begin{array}{l}\text { - I truly/really need this } \\
\text { extension. } \\
\text { Time intensifiers }\end{array}$ \\
& $\begin{array}{l}\text { "Employed to emphasize the temporal aspect of the high fever } \\
\text { speaker's request" (Schauer, 2009, p. 91) }\end{array}$ & $\begin{array}{l}\text { - as soon as possible } \\
\text { - urgently } \\
\text { Overstater }\end{array}$ \\
& $\begin{array}{l}\text { "Exaggerated utterances that form part of the request } \\
\text { and are employed by the speaker to communicate their } \\
\text { need of the request being met" (Schauer, 2009, p. 91) }\end{array}$ & $\begin{array}{l}\text { - I'm in desperate need of } \\
\text { material for my essay. }\end{array}$ \\
\hline
\end{tabular}

The external modifications were calculated as a whole email message. This means that the frequency of occurrence will only be measured following the occurrence in each message. The reason behind of this coding system is that the nature of emails that we collected. One email message often carries two request head acts while the sender writes it in one single email. Following this procedure, there were a total of 74 request heads found from the 56 email messages. The coding schemes for external modification are presented in Tables 3 and 4.

Table 3. External modification coding framework - Supporting moves

(Economidou-Kogetsidis, 2011, p. 3211-3212)

\begin{tabular}{|c|c|c|}
\hline Name & Explanation & Examples \\
\hline Greeting/opening & The writer opens the email with a greeting & $\begin{array}{l}\text { - Hi/Hello/Good morning } \\
\text { - How are you? } \\
\text { - I am sorry to hear that you } \\
\text { are not well. }\end{array}$ \\
\hline Self-introduction & The writer introduces himself/herself & $\begin{array}{l}\text { I'm Maria K. from your LALI- } \\
141 \text { class }\end{array}$ \\
\hline Grounder & $\begin{array}{l}\text { A clause which can either precede or follow a } \\
\text { request and allows the speaker to give reasons, } \\
\text { explanations, or justifications for his or her } \\
\text { request }\end{array}$ & $\begin{array}{l}\text { 'I would like an assignment } \\
\text { extension because I could not } \\
\text { deal the typing time.' }\end{array}$ \\
\hline Disarmer & $\begin{array}{l}\text { A phrase with which "the speaker tries to } \\
\text { remove } \\
\text { any potential objections the hearer might raise } \\
\text { upon being confronted with the } \\
\text { request" (Blum-Kulka et al., } 1989, \text { p. } 287 \text { ) }\end{array}$ & $\begin{array}{l}\text { 'I know that this assignment is } \\
\text { important but could you...?' } \\
\text { 'I hope you understand my } \\
\text { situation...' }\end{array}$ \\
\hline Preparator & $\begin{array}{l}\text { The speaker prepares the hearer for the ensuing } \\
\text { request. }\end{array}$ & 'I really need a favour...' \\
\hline $\begin{array}{l}\text { Getting a } \\
\text { precommitment }\end{array}$ & $\begin{array}{l}\text { The speaker checks on a potential refusal before } \\
\text { performing the request by trying to get the } \\
\text { hearer to commit }\end{array}$ & 'Could you do me a favor?'. \\
\hline Promise & $\begin{array}{l}\text { The speaker makes a promise to be fulfilled } \\
\text { upon completion of the requested act }\end{array}$ & $\begin{array}{l}\text { 'Could you give me an } \\
\text { extension? I promise I'll have } \\
\text { it ready by tomorrow. '. }\end{array}$ \\
\hline Imposition minimizer & $\begin{array}{l}\text { "The speaker tries to reduce the imposition } \\
\text { placed on the hearer by his request" (Blum- } \\
\text { Kulka et al., 1989, p. 288). }\end{array}$ & $\begin{array}{l}\text { 'I would like to ask for an } \\
\text { extension. Just for a few days. } \\
\text { ' }\end{array}$ \\
\hline Apology & $\begin{array}{l}\text { The speaker apologizes for posing the request } \\
\text { and/or for the imposition incurred. }\end{array}$ & $\begin{array}{l}\text { 'I'm very sorry but I need an } \\
\text { extension on this project. ' }\end{array}$ \\
\hline Orientation move & $\begin{array}{l}\text { Opening discourse moves which serve an } \\
\text { orientation function but do not necessarily } \\
\text { mitigate or aggravate the request in any way }\end{array}$ & $\begin{array}{l}\text { 'You know the seminar paper } \\
\text { I'm supposed to be giving on } \\
\text { the } 29 \text { th ...' }\end{array}$ \\
\hline
\end{tabular}




\begin{tabular}{|c|c|c|}
\hline & & $\begin{array}{l}\text { 'It about our midterm exam' } \\
\text { 'I have a question about the }\end{array}$ \\
\hline Complement/sweetener & $\begin{array}{l}\text { "Employed to flatter the interlocutor and to put } \\
\text { them into a positive mood", } \\
\text { (Schauer, 2009, p. 92) }\end{array}$ & $\begin{array}{l}\text { 'Your opinion counts' } \\
\text { 'I hope you feel better' }\end{array}$ \\
\hline Pre-closings/thanks & & $\begin{array}{l}\text { 'Thanks for your time' } \\
\text { 'I look forward to hearing from } \\
\text { you' }\end{array}$ \\
\hline Email closing & & Best, Sincerely, \\
\hline
\end{tabular}

Table 4. External modification coding framework - Aggravating moves

(Economidou-Kogetsidis, 2011, p. 3211-3212)

\begin{tabular}{ll}
\hline \multicolumn{1}{c}{ Name } & \multicolumn{1}{c}{ Examples } \\
\hline Complaint/criticism & 'I sent you an email 3 days ago and never replied' \\
& 'I need to have the reference letter in three days.' \\
$\begin{array}{l}\text { Emphasis on urgency/positive } \\
\text { outcome }\end{array}$ & 'I will expect your positive reply' \\
\hline
\end{tabular}

\section{Results}

\subsection{Internal modifications (Lexical/phrasal downgraders)}

Tables 5 and 6 present the results of the occurrence and the type of internal modifiers from a total of 74 request head acts that occurred in the email data. The finding showed that the majority of the email requests involved no lexical/phrasal downgraders or the so-called zero-marking (44.5\%). This suggests that the requests made by Indonesian students appeared to be under modified. The type of modifiers used was also very limited. Generally, the pattern showed that students frequently used three types of internal modifiers, i.e., marker 'please' (18\%), consultative devices (13.5\%), and time intensifier (8.1\%). Other modifiers such as appealers, downtoners, and understaters were used once while others, i.e., cajolers and subjectivisers were not used at all.

Marker 'please' came as the most frequently used among the restricted ranges of internal modifiers. The students employed marker 'please' mainly to ask their professors to provide feedback on their academic writing/papers. The emails [1] and [2] below are examples from our data:

[1]

Dear Last Name (LN)-Sensei,

This my draft for my letter of recommendation. Please feel free to edit it if you wish [marker 'please']. Thank you very much for taking some time on this matter.

Best regards,

Student BH

Table 5. Distribution of internal modification (Lexical/phrasal downgraders)

\begin{tabular}{lc}
\hline Type & Total (percentage) \\
\hline Zero marking & $33 / 74(44.5 \%)$ \\
Marker 'please' & $13 / 74(17,5 \%)$
\end{tabular}


Consultative devices

Downtoners

Understarters/ hedges

Subjectivisers

Cajolers

Appealers
$10 / 74(13.5 \%)$

$1 / 74(1.3 \%)$

$1 / 74(1.3 \%)$

0

0

$1 / 74(1.3 \%)$

Table 6. Distribution of internal modifications (Upgraders- Intensifiers)

\begin{tabular}{lc}
\hline Type & Total (percentage) \\
\hline Intensifier & $3 / 74(4.05 \%)$ \\
Time intensifiers & $6 / 74(8.1 \%)$ \\
Overstater & 0 \\
\hline
\end{tabular}

\section{[2]}

\section{Dear LN Sensei,}

Good afternoon. I hope this email finds you well.

I forward the email from ***-event. Please check the following email [marker 'please'].

Thank you very much.

Best regards,

Student DF

It can be observed that the pattern of the marker 'please' in our email data functions as illocutionary force indicator (Faerch \& Kasper, 1989). This modifier was employed as students' strategy to create an explicit expression of request. The students showed a tendency to use the marker 'please' followed by imperative, as shown in examples in [1] and [2]. The high occurrence of 'please' + imperative mirrors the finding of Biesenbach-Lucas (2002) and (2007), Hartford \& Bardovi-Harlig (1996), Faerch \& Kasper (1989), and Sirikhan \& Prapphal (2011). It is argued that this has become interlanguage pragmatic features across different proficiency levels (House, 1989).

The second frequently used internal modifiers was consultative devices. In their email, the students looked for the professor's cooperation and/or opinion regarding their requests by using phrasal such as, is it okay (example [3]), or should I. This strategy inherently can soften the imposition of the requests as the students show that that compliance is not given, and it depends on the professors whether or not to grant the request that the students asked.

\section{[3]}

Dear FN+LN Sensei,

Konnichiwa (Japanese: hello)

Sensei, I would like to give an information that I have completed the required documents and going to send via post mail to academic Affairs Division. Just in case, Is it okay for me to send the documents directly to academic Affairs Division without the recommendation letter in it [consultative devices]?

I am looking forward to hearing from you

Best Regards,

Student JM 
It is argued that the high occurrence of this modifier is due to their L1 influence. This downgrader has an equivalent in the Indonesian language (apakah bisal apakah boleh?). It has the same function to mitigate requests, and therefore it is no doubt that this downgrader is relatively popular among the Indonesian students.

A further significant finding of this study concerned the use of time intensifier. In contrast to the findings of Economidou-Kogetsidis (2011), where the NNS students were perceived as rude when including time intensifier in their requests, the preference to use time intensifier as found in this study was not quite the same. The students in Economidou-Kogetsidis (2011) were found to emphasize on urgency and gave the professors unreasonable time frames by using a phrasal such as as soon as possible, however, in this study, it seems that the Indonesian students chose to include the time intensifier in their emails as to provide clarity in regards to the information about a deadline (see examples [4] and [5]. In the academic context, students do not want to make a bold request which sounds abrupt. Still, on the other hand, they also work with a timeline; therefore, by explicitly mentioning the time expectation or the deadline of a task, it will not only provide the clarity of the message but also can ease the professor, so they know when the favor is expected.

[4]

The deadline for collecting form is March 13 (Tues) at $4 \mathrm{pm}$ [Time intensifier] I hope you do not mind to fill the form.

[5]

This is a friendly reminder that the conference *** 2017 for abstract submission is due today. I am expected to submit this by next week (August 23th) [Time intensifier]. I hope you don't mind writing this for me.

\subsection{External modifiers (supporting and aggravating moves)}

The results presented in Table 7 showed that there were more varieties of external modifications used by the students, including email closing $(87.5 \%)$, pre-closing/thanks $(76,7 \%)$, discourse orientation moves $(73,2 \%)$, email closing (58\%), and grounders $(48,2 \%)$. They also used other moves such as opening move, complement/ sweetener, self-introduction, apology, and appreciation statement, although the numbers were not significant (see Table 7). Other moves such as disarmer, preparatory, getting precommitment, and promise moves were not used at all. None of the emails collected contained any aggravating moves (Table 8).

Table 7. External modification in students' emails: Supporting moves

\begin{tabular}{lc}
\hline Type & Total \\
\hline Greeting/opening & $13 / 56(23.2 \%)$ \\
Self-introduction & $9 / 56(16 \%)$ \\
Discourse orientation move & $42 / 56(75 \%)$ \\
Grounder & $27 / 56(48.2 \%)$ \\
Appreciation statement & $3 / 56(5.3 \%)$ \\
Disarmer & 0 \\
Preparatory & 0
\end{tabular}




$\begin{array}{lc}\text { Getting precommitment } & 0 \\ \text { Promise } & 0 \\ \text { Imposition minimizer } & 0 \\ \text { Apology } & 9 / 56(16.07 \%) \\ \text { Complement/ sweetener } & 12 / 56(21.42 \%) \\ \text { Pre-closing/ thanks } & 43 / 56(76,7 \%) \\ \text { E-mail closing } & 49 / 56(87.5 \%)\end{array}$

Table 8. External modification in students' emails: Aggravating moves

\begin{tabular}{lc}
\hline Type & Total (percentage) \\
\hline Complaint/criticism & 0 \\
Emphasis on urgency & 0 \\
\hline
\end{tabular}

Regardless of the bare use of lexical/phrasal downgraders, it is worth noting that the majority of the students made sure that they properly closed their emails (87.5\%) and signed with their names. The following email is an example from the data:

[6]

Dear LN sensei,

Ohayougozaimasu sensei (Japanese: good morning) [greeting], This is my research proposal, I submit below.

Thank you so much and I look forward to hear from you sensei.

Have a nice day [Pre-closing].

Best regards, [closing]

Student MF [signature]

The majority of the emails also contain pre-closing/thanks move (43 out of 56 emails), as shown in examples [1], [2] and [3]. It comes as no surprise that the Indonesian students employed this supportive move after mentioning the requests or before closing their messages. In many cultures, including Indonesian culture, to be polite means to say thank you whether the request will be granted or not. This can be understood as the requester's strategy to show politeness when s/he feels that the way $\mathrm{s} / \mathrm{he}$ performs the request is not adequate to meet the level of politeness that the recipient expects.

Furthermore, the results showed that $73,2 \%$ of the emails contained Discourse Orientation Moves (DOM) before mentioning their request. Woodfield and Economidou-Kogetsidis (2010, p. 92) define DOM as "opening discourse moves, which serve an orientation function but do not necessarily mitigate or aggravate the request in any way." The students used the DOM as an introduction of the message and/or share background information. It also can show the direction of the speech. The following email messages are examples of the use of DOM in our data: 
[7]

Dear LN-Sensei,

This is the latest version of my paper [DOM]. I hope Sensei have same time to give some feedback.

[8]

Respected LN Sensei,

as you instruction related with book written, yesterday [DOM]. I attach my research power point in below. Hopefully, I can get feedback to increase the quality of this research and also can be appropriate in chapter of sensei's book.

[9]

Dear LN sensei

I hope this email finds you well.

I intend to apply for *** Scholarship [DOM].

This scholarship is available for Indonesian student.

I really hope I can apply.

The deadline for collecting form is March 13 (Tues) at $4 \mathrm{pm}$. I hope you do not mind to fill the form.

The next supporting move that was also frequently used was grounders. Grounders are reasons or explanations embedded in the request. This can appear before or after the request head act as shown in the following examples.

[10]

Respected Sensei,

i want to inform that i cannot come to the lab till a week later because of illness [grounder]. it means i cannot join both seminar. i'm so sorry to say that. [apology]

i put the letter from doctor in this email, also.

hope you understand it. thank you sensei

[11]

Because I can not find the website for registration this trip [grounder], therefore I hope this email can represent it.

\section{Discussion}

Regardless of the strictly narrow type and the low frequency of the internal modifiers used, the analysis of this study shows that the Indonesian students seem to rely more on the use of external modification strategy to soften the force of their requests. This general finding is consistent with the findings from abundant request modification studies (Economidou-Kogetsidis, 2011; Hassal, 2012; Hartford \& Bardovi-Harlig, 1996; Hendriks, 2010; Pan, 2012; Woodfield \& Economidou-Kogetsidis, 2010; Zarei \& Mohammadi, 2012. Hassal (2012) claims that the combination of these two salient features, i.e., restricted range use of internal modifications and abundant use of external modifications might be a characteristic of L2 speech act because they are pragmalinguistically less complex and syntactically less demanding as external modifiers usually only construct a simple clause. This preference can also be due to a lack of linguistic flexibility to select lexicon syntactic modifiers (Biesenbach-Lucas $(2004,2006)$. Even though they perform the request in emails, which allows them 
to have more processing time to write their requests, these students may choose to avoid the complex structures by avoiding adding internal modifications in their emails.

A further explanation offered for this finding is that the internal modifiers such as cajolers (e.g., 'you know'), which was absent in this study, might not be seen as appropriate to be used in written discourse. Communicating with a professor in an academic context requires some degree of formality; therefore, the students possibly choose to avoid using this phrasal in their written communication.

As previously discussed, the lack of internal modifications used by the Indonesian students can be seen as a result of their L1 influence. The internal modifiers, such as 'subjectivisers', have no functional equivalent in the Indonesian language. Unlike politeness marker 'please', which has the equivalent in Indonesian 'tolong' and functions to mitigate the force of requests, subjectivisers, e.g., 'I wonder' (saya kira/ saya pikir) does not function as a request mitigator in the students' mother tongue.

While the bare use of internal modifications is deemed as causing pragmatic failure and also deviates from British English native speakers' norms of politeness (Economidou-Kogetsidis, 2011), the results in this present study demonstrate that this is not necessarily the case. Our findings on the students' strong reliance on the use of external modifiers at least hint that these students actually show their effort to write status-congruent emails as the external modifiers itself carry explicit politeness function (Faerch \& Kasper, 1989, p. 243). Even though the students seem to have limited linguistic resources in the form of internal modifiers, they ensure that they include the external modifiers to write a politer email request to a person with higher social power. As shown from the results, generally, the students write their requests by providing background information of the request through discourse orientation move (DOM). They also opt to supplement their emails with sufficient reason or explanations of why they make their request through the grounder move. Lastly, they assure that they express their gratitude and appreciation for imposing the professors in the form of 'thank you move' before closing their emails.

Moreover, the linguistic behaviors shown by the students in this study can be a typical requesting behavior in email communication and not necessarily NNSs' requesting behavior, as noted by Biesenbach-Lucas (2006) and Economidou Kongetsidis (2011). Request realizations performed by American NS students in Biesenbach-Lucas (2006) were also not overly adorned with internal modifications.

Following this, it can be concluded that students who grow up in an instant messaging culture as the students in this study seem to value brevity and, therefore, as long as they present basic politeness features, e.g., through the use of supporting moves, it will be considered as sufficient for stating the request. This does not indicate a decrease in respect towards the university professors, but rather a changing communication style; nevertheless, this claim certainly needs validation in further research.

Because of the lack of balance in the email corpus, particularly the proportion of the type of request collected, we decided not to investigate the requests based on the request type and its imposition level as in Hartford \& Bardovi-Harlig (1996) or Zhu (2012). A request which carries more imposition, such as asking the professor to write a recommendation letter, is expected to have some degree of formality (Wang \& Aaltonen, 2004) and an epistolary style compare to a request which only asks for information about the university course. This might also play a role when the students opt to modify their email requests with internal modifications as they might feel to better directly straight to the point without taking too much time of the professor to read their emails. Therefore, further research can look at how the students use request modifications in regards to the type of request and the 'weight' of their requests and see whether such requests need particular modifiers or not. 


\section{Conclusion}

This study was intended to examine the request modifications employed by Indonesian students when making English email requests to Japanese professors. The strategies were carried out both through internal and/or external modifications to soften the imposition of the requests. Overall, the findings of this study indicated a number of patterns. First, Indonesian students appear to have a restricted range of internal modifications to soften the force of the request in their emails. Second, evidence suggests that they compensate this by relying more on the use of external modifications in the form of supporting moves. The range and the frequency of supporting moves used in their emails to some extent indicate that while they tried to be as brief and explicit as possible, some basic politeness features as seen from the use of supporting moves in their email indicates that the Indonesian students in this study tried to demonstrate some degree of politeness.

\section{Ethics Committee Approval}

The author(s) confirm(s) that the study does not need ethics committee approval according to the research integrity rules in their country (Date of Confirmation: August 27, 2020).

\section{References}

Al-Gahtani, S., \& Roever, C. (2013). 'Hi doctor, give me handouts': Low-proficiency learners and requests. ELT Journal, 67(4), 413-424.

Biesenbach-Lucas, S. (2004). Speech acts in e-mail: A new look at pragmatic competence. Paper presented at the Annual Convention of the American Association of Applied Linguistics, Portland, OR.

Biesenbach-Lucas, S. (2006). Making requests in email: Do cyber-consultations entail directness? Toward conventions in a new medium. In K. Bardovi-Harlig, J. C. Felix Brasdefer, \& A. Omar (Eds.), Pragmatics and language learning (pp. 81-107). Honolulu, HI: [National Foreign Language Resource Center] University of Hawaii Press.

Biesenbach-Lucas, S. (2007). Students writing emails to faculty: An examination of e-politeness among native and non-native speakers of English. Language Learning \& Technology, 11(2), 59-81.

Blum-Kulka, S., \& Olshtain, E. (1984). Requests and apologies: A cross-cultural study of speech act realization patterns (CCSARP). Applied Linguistics, 5(3), 196-213. https://doi.org/10.1093/applin/5.3.196

Blum-Kulka, S., House, J., \& Kasper, G. (Eds.). (1989). Cross-cultural pragmatics: Requests and apologies. Norwood, NJ: Ablex.

Brown, P., \& Levinson, S. C. (1987). Politeness: Some universals in language usage. In Brown, P., \& Levinson, S. C (Eds.), Politeness: Some universals in language usage, (pp. 311-323). Cambridge, UK: Cambridge University Press.

Chen, C-F. E. (2006). The development of e-mail literacy: From writing to peers to writing to authority figures. Language Learning \& Technology, 10(2), 35-55.

Deveci, T., \& Hmida, I. (2017). The request speech act in emails by Arab university students in the UAE. Journal of Language and Linguistic Studies, 13(1), 194-214. 
Economidou-Kogetsidis, M. (2009). Interlanguage request modification: The use of lexical/phrasal downgraders and mitigating supportive moves. Multilingua, 28(1), 79111. https://doi.org/10.1515/mult.2009.004

Economidou-Kogetsidis, M. (2011). "Please answer me as soon as possible": Pragmatic failure in nonnative speakers' email requests to faculty. Journal of Pragmatics, 43(13), 3193-3215. https://doi.org/10.1016/j.pragma.2011.06.006

Faerch, C. \& Kasper, G. (1989). Internal and external modification in interlanguage request realization. In S. Blum-Kulka, J. House, \& G. Kasper (Eds.), Cross-cultural pragmatics: Requests and apologies (pp. 221-247). Norwood, NJ: Ablex.

Félix-Brasdefer, J. C. (2012). Email requests to faculty. In M. Economidou-Kogetsidis, \& H. Woodfield (Eds.), Interlanguage request modification (pp. 87-188). John Benjamins Publishing. https://doi.org/10.1075/pbns.217.04fel

Fukushima, S. (1996). Request strategies in British English and Japanese. Language Sciences, 18 (34): 671-688. https://doi.org/10.1016/S0388-0001(96)00041-1

Hartford, B. \& Bardovi-Harlig, K. (1996). "At your earliest convenience": A study of written student requests to faculty. In L. F. Bouton (Ed.), Pragmatics and language learning. Monograph Series Volume 7 (pp. 55-69). Urbana, IL: DEIL

Hassall, T. (1999). Request strategies in Indonesian. Pragmatics. Quarterly Publication of the International Pragmatics Association (IPrA), 9(4), 585-606.

Hassall, T. (2001). Modifying requests in a second language. International Review of Applied Linguistics (IRAL), 39, 259-283.

Hassall, T. (2012). Request modification by Australian learners of Indonesian. In M. EconomidouKogetsidis, \& H. Woodfield (Eds.), Interlanguage request modification (pp. 203-242). Amsterdam: John Benjamins.

Hendriks, B. (2010). An experimental study of native speaker perceptions of non-native request modification in emails in English. Intercultural Pragmatics, 7(2), 221-155. https://doi:10.1515/iprg.2010.011

House, J. (1989). Politeness in English and German: The functions of 'please' and 'bitte'." In S. BlumKulka, J. House, \& G. Kasper (Eds.), Cross-cultural pragmatics: Requests and apologies (pp.123154). Norwood, NJ: Ablex.

Pan, C. (2012). Interlanguage requests in institutional email discourse. In M. Economidou- Kogetsidis \& H. Woodfield (Eds.), Interlanguage request modification (pp. 119-161). Amsterdam: John Benjamins.

Searle, J. R. (1969). Speech acts: An essay in the philosophy of language. Cambridge University Press.

Sirikhan, S., \& Prapphal, K. (2011). Assessing Pragmatic Ability of Thai Hotel Management and Tourism Students in the Context of Hotel Front Office. Asian EFL Journal Professional Teaching Articles, 53, 72-94.

Wang, M., \& Aaltonen, S. (2004). Sino-Finnish e-mail project: A teaching tool for tertiary business communication course. The Asian ESP Journal, 6(3).

Woodfield, H. \& Economidou-Kogetsidis, M. (2010). 'I just need more time': A study of native and nonnative students' requests to faculty for an extension. Multilingua, 29(1), 77118. https://doi.org/10.1515/mult.2010.004 
Zarei, G. R. \& Mohammadi, M. (2012). E-politeness in Iranian English electronic requests to the faculty. Research in Applied Linguistics, 3(1), 3-24.

Zhu, W. (2012). Modal Verbs [1] for politeness in e-mail requests to professors: The case of Chinese EFL learners. The Asian EFL Journal, 14, 100-141.

\section{E-postalarda profesörlere talepte bulunma: Japonya'daki Endonezyalı öğrenciler tarafından gerçekleştirilen talep değişikliklerinin incelenmesi}

\section{$\ddot{\mathbf{O z}}$}

Bu makale, Endonezyalı öğrenciler tarafından, ortak dil olarak İngilizceyi kullanan Japon üniversite profesörlerine gönderilen e-posta taleplerini incelemektedir. Özellikle, empoze edilen taleplerin gücünü yumuşatmak için iç ve dış değişiklikleri kullanarak öğrencilerin e-posta taleplerini nasıl değiştirdiklerini analiz eder. Veriler, toplam 56 gerçek e-postadan toplandı. Sonuç, Endonezyalı öğrencilerin yazılı taleplerinin dayatmasını yumuşatmak için dahili değişiklikleri zar zor kullanırken, destekleyici hareketleri kullanarak harici değişikliklerin kullanımına daha fazla güvenme eğiliminde olduklarını gösterdi. Bu strateji, öğrenciler profesörlerine yeterli arka plan bilgisi sağladıklarından ve gerekçeli hareketler yoluyla taleplerinin arkasındaki sebebi doğruladıklarından, talebin sözsüz gücünü dolaylı olarak değiştirebilir. Bu çalışma aynı zamanda öğrencilerin iletişim tarzlarında kısalığın yüksek oranda tercih edildiğini göstermektedir.

Anahtar Sözcükler: e-posta; kültürlerarası iletişim; değişiklik talep etmek; pragmatik; Endonezyalılar

\section{AUTHOR BIODATA}

Rezky Pratiwi Balman is a Ph.D. candidate at the Graduate School of Integrated Sciences for Global Society, Kyushu University, Japan. She holds a Master of Applied Linguistics from the University of Melbourne, Australia. Her research interests include teaching English as a Lingua Franca, technology-assisted language learning, and intercultural pragmatics.

Sangmok Lee is an associate professor in the Faculty of Languages and Cultures at Kyushu University, Japan. His research interest includes foreign language education using multimedia and the formation of image schema. 